Volume 16, Number 1, Juni 2019

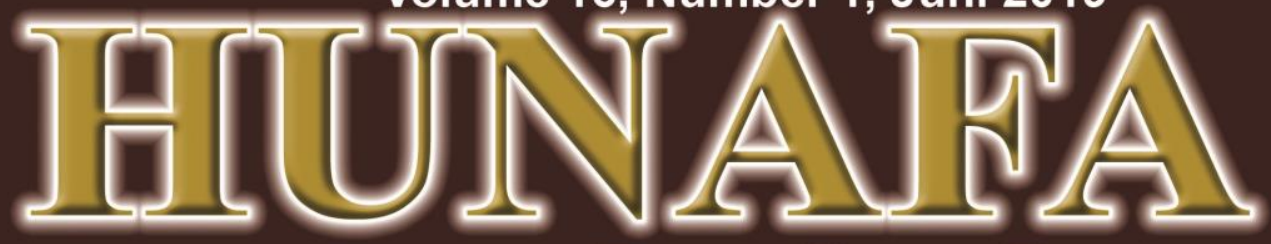

Jurimal Stradial Islamilka

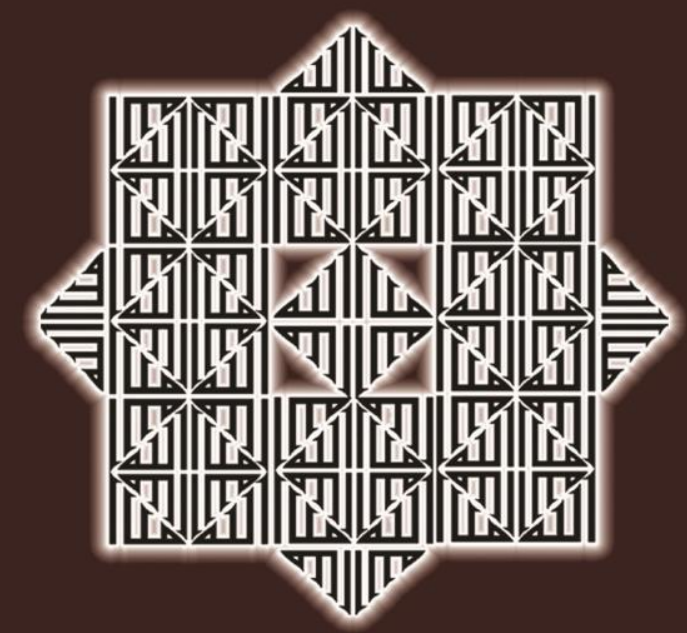

ALKHAIRAAT POLITICAL CHARISMA Syamsuri

IRAN REVOLUTION, ECONOMIC STRUGGLE AND INDEPENDENCE UNDER PRESSURE Meirizon Alizar Ali

\author{
MARKETING PERFORMANCE DETERMINANT \\ OF HALAL PRODUCTS IN INDONESIA \\ Confirmatory Factor Analysis Approach \\ Aan Nasrullah
}

State lnstitute for lsiamic Studies (ILAIN) Palu central Sulawesi

\begin{tabular}{|c|c|c|c|c|c|}
\hline $\begin{array}{c}\text { HUNAFA } \\
\text { JSI }\end{array}$ & $\begin{array}{c}\text { Volume } \\
16\end{array}$ & $\begin{array}{c}\text { Number } \\
1\end{array}$ & $\begin{array}{c}\text { Page } \\
1-153\end{array}$ & $\begin{array}{c}\text { Palu } \\
\text { Juni } 2019\end{array}$ & $\begin{array}{c}\text { ISSN } \\
\text { 141-125X }\end{array}$ \\
\hline
\end{tabular}




\section{HUNAFA}

Jurnal Studia Islamika

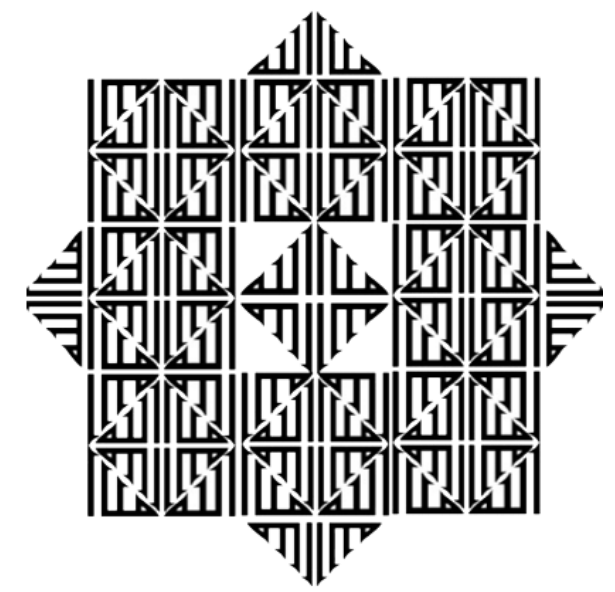

Published by:

State Islamic Institute (IAIN) Palu

Central Sulawesi 


\section{HUNAFA}

Jurnal Studia Islamika

HUNAFA: Jurnal Studia Islamika is an Islamic studies journal dedicated to publishing scholarly articles on all aspects of Islam and the Muslim peoples and religious studies. Available in print and online and published twice a year, the journal aims to become one of the leading platforms in Indonesia for new findings and discussions of all fields of Islamic studies. This journal invites scholars, researchers, and students to contribute the result of their studies and researches in the areas related to Islam and Muslim society which covers textual and fieldwork investigation with various perspectives of law, education, quranic studies, economiy, philosophy, mysticism, theology, sociology, and others.

\section{CAll rights reserved}

No part of this publication may be reproduced in any form without written permission from HUNAFA, to whom all requests to reproduce copyright material should be directed. HUNAFA grants authorization for individuals to photocopy copyright material for private research use. This authorization does not extend to any other kind of copying, by any means, in any form, and for any purposes other than private research.

\section{Open Acces Journal Information}

The journal provides immediate open access to its content on the principle that making research freely available to the public supports a greater global exchange of knowledge. The journal offers full access contents at http://jurnalhunafa.org.

\section{Printed Journal Subscription Information}

Institution Rp 100.000,00 /issue; Rp 1.100.000,00/year

Individual: Rp. 60.000,00/issue; Rp. 600.000,00/year

Outside Indonesia (individual or institution) \$60/month; \$600/year

For detail information of printed journal subscription, feel free to contact the journal manager at hunafajournal@gmail.com.

\section{Mailing Address}

HUNAFA: Jurnals Studia Islamika

Lembaga Penelitian dan Pengabdian Masyarakat (LP2M) IAIN Palu 
Jl. Diponegoro No. 23 Palu, Sulawesi Tengah 94221 Indonesia

Phone: +62-451-460798; Fax: +62-451-460165

E-mail: jurnalhunafa@yahoo.com; hunafajournal@gmail.com

Website: www.jurnalhunafa.org

HUNAFA

Jurnal Studia Islamika

\section{EDITOR-IN-CHIEF}

Nurdin, Institut Agama Islam Negeri Palu, Indonesia

\section{EDITORIAL BOARD}

Sagaf S. Pettalongi, Institut Agama Islam Negeri Palu, Indonesia

Rusli, Institut Agama Islam Negeri Palu, Indonesia

Tulus Suryanto, Universitas Islam Negeri Raden Intan Lampung, Indonesia

Ade Yeti Nuryantini, Universitas Islam Negeri Sunan Gunung Djati, Indonesia

Toto Suharto, Institut Agama Islam Negeri Sukoharjo, Indonesia

Reza Fahmi, Universitas Islam Negeri Imam Bonjol Padang, Indonesia

Mohamad Abdalla, University of South Australia, Australia

Cucuk Wawan Budiyanto, Universitas Sebelas Maret, Indonesia

Kevin W. Fogg, University of Oxford, United Kingdom

Al Makin, Universitas Islam Negeri Sunan Kalijaga Yogyakarta, Indonesia

Miftachul Huda, Universiti Teknologi Malaysia, Malaysia

Hendri Tanjung, Ibn Khaldun University Bogor, Indonesia

Muhammed Modassir Ali, Hamad bin Khalifa Universty, Qatar

Hamid Fahmi Zarkasyi, Universitas Darussalam Gontor, Indonesia 


\section{MANAGING EDITOR}

Mohammad Nur Ahsan, Institut Agama Islam Negeri Palu, Indonesia

\section{COVER DESIGN}

Lukman Latif 


\section{HUNAFA \\ Jurnal Studia Islamika}

\section{Contents}

Editorial

vi-vii

AL-KHAIRAAT POLITICAL KHARISMA

$1-18$

Syamsuri

BANGRENG AS A MEANS OF SPREADING ISLAM

Melyan Sofian, Cece Sobarna, Reiza D. Deinaputra, Deni Hermawan

FOREIGN LANGUAGE TEACHING AND INFORMATION COMMUNICATION TECHNOLOGY: IS THERE OPPORTUNITY FOR QURANIC LANGUAGE TEACHERS?

Nuril Mufidah, Abduganiy Abimbola Abdussalam, Aliy Abdulwahid Adebisi

IRAN REVOLUTION, ECONOMIC STRUGGLE AND INDEPENDENCE UNDER THE PRESSURE

Meirozon AlizarAli 
Umi Salamah

MAHRAM IMPLICATIONS IN WOMEN'S TRAVEL

$88-110$

Maulidah Tri Utami

MARKETING PERFORMANCE DETERMINANT

OF HALAL PRODUCTS IN INDONESIA:

Confirmatory Factor Analysis Approach

Aan Nasrullah

RELATIONS BETWEEN MOSQUE AND

$142-153$

SOCIAL HISTORY OF ISLAMIC EDUCATION

Anna Triayudha, Rateh Ninik Pramitasary, Hermansyah Akbar Anas, Choirul Mahfud 


\section{Editorial Preface}

Nurdin Nurdin, Institut Agama Islam Negeri (IAIN) Palu

This issue (Vol. 16 issues 1) of Hunafa: Jurnal Studia Islamika offers eight articles covering topics of Islamic studies. Various issues relating to Islamic studies are presented interestingly to contribute to the body of knowledge and practices. Academia and practitioners in Islamic studies may gain insight from reading these articles.

The first article is titled "Al-Khairaat Political Kharisma" by Syamsuri Syamsuri from Department of Dakwah, Faculty of Ushuluddin, Adab, and Dakwah, Institut Agama Islam Negeri Palu. This paper discusses the roles of Al-Khairaat in politics arena within local and national level. Several political parties have come to the Alkhairaat organization to recruit political cadres in the face of general election events.Alkahiraat's political charisma in the frame of political communication includes the participation, consolidation, and partnership of Alkhairaat politicians who spread in various political parties to win the election contestation.

The second article in the issue is titled "Bangreng as a Means of Spreading Islam" by Maylan Sofian, Cece Sobarna, Reiza D. Dienaputra, and Deni Hermawan from STKIP Sebelas April Sumedang. This paper describe Bangreng culture which was originally an example used by the Sumedang community as a medium to express gratitude for everything that Allah SWT gave to humans. But the function of art as a ritual began to shift into art as entertainment. This Bangreng art is an art that is very interesting to study because there are only a few different functions. This change does not change the name of the show. With this description, it needs to be isolated, that is, the community does not lose identity. The aim is that the public knows the function of the nation in the spread of Islam.

The third article is titled "Determinants of Halal Product Marketing Performance In Indonesia: Confirmatory Factor Analysis Approach" by Aan Nasrullah. This paper discussed the five variables that contribute to halal product marketing which are product competition, HR marketing performance, infrastructure, amount of distribution cost, and market competition.

The fourth article is titled "Foreign Language Teaching and Information Communication Technology: Is There Opportunity for Quranic Language Teachers?"by Nuril Mufidah, Abdulganiy Abimbola Abdussalam, Aliy Abdulwahid Adebisi from UIN Maulana Malik Ibrahim Malang and University of Ilorin, Ilorin, Nigeria. The article discuses the use of ICT in learning of Arabic. The subjects of the study were students of Arabic Language Education at UIN Maulana Malik Ibrahim Malang Indonesia 2018 academic year and students and Department of Arabic, Faculty of Arts University of Ilorin, Nigeria. The findings of the research are that ICT if adequately harnessed and utilized will go a long way in enhancing the quality of teaching of Arabic, as it was established to teaching other languages of the world.

The fifth article is by Meirizon Alizar Ali dari UIN Imam Bonjol. The article is titled "Iran Revolution, Economic Struggle and Independence under the Pressure" The article discusses 
Iran economy situation after experiencing various kinds of changes in economic policy and facing various kinds of situations Iran succeeded in developing the economy without changing the basics of Islamic shari'ah principles and revolution.

The sixth article is titled "Kaisa Method in Intelligence Multiple Perspective" by Umi Salamah from PGMI, STAI Ma'had 'Aly Al-Hikam, Malang. The article analyzed memorizing the Qur'an using the Kaisa method in the perspective of multiple intelligence. The Kaisa method is a way of memorizing the Qur'an which is oriented to memorization and understanding of the verses of the Qur'an along with their meanings through movements or kinesthetic which are adapted to the meaning of each verse so as to make it easy to understand and remember every verse of the Qur'an given.

The seventh article is titled "Mahram Implications in Women's Travel" by Maulidah Tri Utami from Faculty UshuluddinAdab and Humaniora, IAIN Salatiga. The article discusses mahram as well as a culture of the manner in which a woman is going out of her home or is drawn. From the various resources available this article determine when a woman can compete without mahram.that is how Islam respects and cares for a woman so much that it also notices when a woman is about to travel. Not just one woman, but all Muslim have a rule if a Muslim is to compete for a long time. So, when to reply a Muslim must meet or finish what he needs before taking a sauna.

The last article is titled "Relations Between Mosque And Social History of Islamic Education" by Choirul Mahfud Anna Triayudha, Rateh Ninik Pramitasary, and Hermansyah Akbar Anas from Institut Teknologi Sepuluh Nopember, Surabaya and Pascasarjana Universitas Muhammadiyah Sidoarjo. The article describe the early period of Islamic education, the Prophet provided exemplary by building and empowering mosques. The example of the Prophet continued with the Caliphs afterwards until the present era. The mosque was built by the Prophet from the Al Haram mosque located in Makkah, Quba Mosque located in Quba, Nabawi mosque located in Medina and so on. The role and function of the mosque at that time was as a place of prayer, a place of prayer, a place for discussion or deliberation, a meeting place to develop a war strategy and others related to the problems and needs of Muslims. From time to time, the role or function of the mosque has changed slightly. In essence, mosques are currently influencing the development of the social history of Islamic education in Indonesia.

I hope the articles presented in this issue add further empirical evidence to the growing body of research that examines various fields from Islam perspectives. The articles could trigger other research to study other field of study with Islam perspectives Islamic institutions in Indonesia.

Nurdin Nurdin

Editor-in-Chief

HUNAFA: Jurnal Studia Islamika

XVI, 1 
Jurnal Hunafa: Studia Islamika, Volume 16, Number 1, p. 88-110

E-ISSN: 2355-7710

P-ISSN: 1411-125X

\title{
MAHRAM IMPLICATIONS IN WOMEN'S TRAVEL
}

Maulidah Tri Utami ${ }^{1}$

${ }^{1}$ Faculty Ushuluddin Adab and Humaniora, IAIN Salatiga, Salatiga, saputra.tami@yahoo.com

\begin{abstract}
There's lot of women who don't just want to hang out at home, makes a women want to look for other things outside the house like work, study, or something. But in Islam there is a rule when a woman is going out of her home or is answering. The article will discuss mahram as well as a culture of the manner in which a woman is going out of her home or is drawn. Who is mahram to accompany a woman on a trip? How are all the provision a woman must make if answering?.From the various resources available to us to determine, when a woman can compete without mahram.that is how Islam respects and cares for a woman so much that it also notices when a woman is about to travel. Not just one woman, but all muslim have a rule if a Muslim is to compete for a long time. So, when to reply a Muslim must meet or finish what he needs before taking a sauna.
\end{abstract}

Keywords: Safar, Mahram, Radlaah, Mushaharah

\begin{abstract}
Abstrak. Banyak seorang wanita yang tidak hanya ingin bersantai di rumah, membuat seorang perempuan ingin mencari hal lain yang berada di luar rumah seperti bekerja, belajar, atau hal lain. Akan tetapi dalam Islam ada aturan apabila seorang perempuan hendak keluar rumah atau bersafar. Dalam artikel ini akan membahas mahram dan juga adab-adab bagaimana seorang perempuan yang hendak keluar
\end{abstract}


rumah atau bersafar. Siapa mahram yang berhak menemani seorang wanita bepergian? Bagaiamana ketentuan yang harus dilakukan oleh seorang wanita jika bersafar? Dari berbagai sumber dalil yang ada sehingga kita akan mengatahui kapan seorang perempuan bisa bersafar tanpa mahram. Begitulah Islam sangat menghormati dan menjaga seorang wanita sehingga Islam juga memperhatikan apabila seorang wanita yang hendak bepergian. Tidak hanya seorang wanita saja, akan tetapi seluruh kaum muslim mempunyai aturan apabila seorang muslim tersebut hendak bersafar dalam jangka waktu yang lama. Jadi, apabila hendak bersafar seorang muslim harus memenuhi atau menyelesaikan apa yang ia butuhkan sebelum bersafar.

Kata kunci: Safar, Mahram, Radlaah, Mushaharah

DOI: $10.24239 /$ jsi.v16i1.533.90-112

\section{Introduction}

In the past, people in Greece, Rome, Hindus and several other countries made women only as objects, not subjects who had legal rights as men. Before Islam arrived, in Arab countries many people traded women, made a woman a hereditary, buried alive when a baby girl was born, legalized uncontrollable poligamy, and also the absence of punishment in domestic violence.

After Islam came, the woman's value is very high, not discriminated but very respected and highly valued. There are special rules for a woman.

Traveling is an activity that numerous people do, either to learn, study, or even work abroad. In the olden days, women who wanted to leave their homes 
without their mahram was rarely to be found. Islam regulates everything, even the smallest thing is noticed by Islam. Especially about traveling or safar for a woman, in which there are many conflicting among Islamic scholars either women could leave the house or have to stay in the house?

In the hadith narrated by Imam Muslim, Prophet Salaullahu 'alaihi wasalam said: "it is not lawful for women to travel or do a day trip, except with their mahram." And the hadith from Abu Sa'ad that the Prophet Salaullahu 'alaihi wasalam: Prohibits a woman who traveled during a two-night trip, except with her husband or her mahram (Narrated by Bukhari and Muslim).

We can see from this hadith that a woman who wants to leave must be with her mahram. From there, as a Muslim, you have to know who our mahram are. Not everyone can be a friend to speak to us, especially for a woman. Women's travel is not as easy as men. Like the amount of innate they carry, it does allow a woman to ask someone's help. Some hadiths explain that a woman must be accompanied by her mahram when traveling. The most rational reason is that the mahram can provide security during the trip. It would be nice indeed if a woman wanted to pray with others. Muslimah really needs to know her mahram, because if someone is currently a mahram to us we are not allowed to marry.

\section{Definition of Safar}

The word as sufru is from the word saafir and the word al-musaafiruun is the plural of the word musaafir (people who travel). Both as sufru and musaafiruun have one meaning. The one who made the trip is called musaafir, because of the mask being opened from his face, coming from his place, and his adventures on a vast earth. Called surf because it opens the entire face and morals of the travelers, so that it appears from what was previously hidden. ${ }^{1}$

${ }^{1}$ Said bin Ali Wahf Al Qahthani, ENSIKLOPEDI SHALAT Menurut Al Quran Dan As Sunnah, Terj. M. Abdul Ghafar (Jakarta: timPustaka Imam Syafi'I, 2006), 225 
Jurnal Hunafa: Studia Islamika, Volume 16, Number 1, p. 88-110

E-ISSN: 2355-7710

P-ISSN: $1411-125 \mathrm{X}$

Whereas according to Muhammad 'Amim al-Barkati are:

$$
\text { الخرج من عمارة موضع القامة على قصد مسيرة ثلاثة أيام فما فوقها بألسير الوسط مع الاستراحات المعتادة. }
$$

"Go out from the residence of the mukim to the destination that requires a trip of three days or more which usually requires a break during the trip ${ }^{2}$

There is also a safar meaning according to the jurists

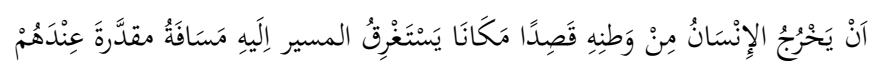

"Someone goes out of his country to go to a certain place, whose journey takes a certain distance in their view" (figh expert) $)^{3}$

It can be concluded that safar is the discharge of a person from one place to another by requiring long trips, rest, and according to custom requires sufficient supplies and allows permissibility of prayer. If a trip is taken on foot it takes approximately three days and three nights. ${ }^{4}$

There are several types of safar that occur such as:

\section{Haram Safar}

Where saafar that is done is the safar that Allah SubhananuWata'ala and Rasulullah salaullahu 'alaihiwasalam forbid. Like safar to trade something that is haram (khamr, stolen property), safar to rob, and also the safar of a person without a mahram.

2. Mandatory Safar

For example safar to go to the obligatory Umrah, or for obligatory jihad, safar people who seek knowledge and safar who do good.

3. Sunnah Safar

${ }^{2}$ Enang Hidayat, Fiqih Ibadah Bagi Orang Sakit dan Bepergian(Bandung: Cendekia Press, 2015), 79 ${ }^{3}$ Ahmat Sarwat, Seri Figh Kehidupan (3): Shalat (Jakarta: Rumah Fiqih Publising, 2015), 494 ${ }^{4}$ Enang Hidayat, Op.Cit., 80-81 
Suppose that Safar is from a person whose umrah is not compulsory, a hajj that is not obligatory

4. Mubah safar

Suppose safar to trade all that is allowed and everything is allowed

5. Makruh safar

For example, if someone is alone without friends except for the interests that must be so. ${ }^{5}$

To do safar one must pay attention to some ethics because Islam has explained a number of adab which must be held by a traveler.

The following are ethics before doing safar:

1. Good intention when going to do safar. ${ }^{6}$

Safar is one of charity (righteousness), it is obligatory to present good intentions, so that every Muslim gets a reward from all the difficulties and costs incurred by him. This good intention will prevent a slave who is still falling into a matter that is hated by Allah subhanahuwata'ala, and wrathed by Him.?

2. Trying to be prepared in the morning, because Rasulullah salaullahu'alaihi wassalam prayed for those who were active in the morning by saying:

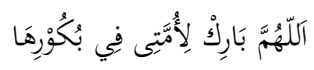

"O Allah give blessings to my people in the morning" (Narrated by Nasai and Tirmidzi $)^{8}$

Why in the morning? Because there is blessing in the morning. ${ }^{9}$

${ }^{5}$ Fadhlihsan,"safardanmacam-macamnya"

(https://www.google.com/amp/s/fadhlihsan.wordpress.com/2010/06/24safar-dan-macammacamnya/amp/), diakses pada 28 Mei 2019, pukul 20.03

"Mahima Diahloka, Buku Pintar "Beribadah Dalam Perjalanan" (Jakarta: Lembar Langit Indonesia, 2016), 31

7 'Abdul'aziz bin Fathi as-Sayyid Nada,Ensiklopedi Adab Islam Menurut Al Quran dan AsSunnah, Terj. Abu Ihsan Al Atsari (Jakarta: tim Pustaka Imam Asy-Syafi'I, 2007), 1

${ }^{8}$ MahimaDiahloka, Op.cit., 31

9 'Abdul'aziz bin Fathi as-Sayyid Nada, Op.Cit., 13 
3. Do the two rak'ah sunnah prayers before taking safar

4. Say goodbye to family and relatives ${ }^{10}$, in other books it is mentioned to be a niyah or will. Where a will is a case that is recommended by Prophetsalalullahualaihiwassalam.

Hestated:

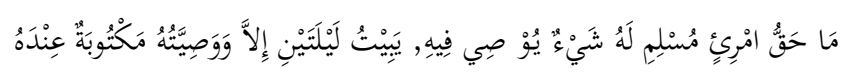

"It is not justified by a Muslim who has something to inherit - he stays for two nights - but his will is written on his side"

Because the person who is doing safar has biger chance to fall in danger or other events. So, he should be serious about carrying out a will to facilitate every right owner in obtaining it. ${ }^{11}$

As for ethics when being on a safar

1. When leaving the house pray with the do'a out of the house, if driving a vehicle also recites prayers that have been taught and safar prayers. If the vehicle for safar has moved, then pray with a prayer narrated by the Prophet salaullahu 'alaihi wassalam, namely:

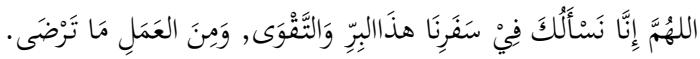

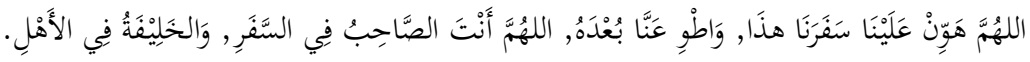

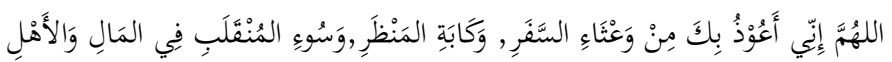

"O Allah, actually we beg for goodness and piety in traveling, we beg for the deeds that you are pleased with. $O$ Allah, make our trip easier, and close the distance for us. $O$ Allah, you are my companion in traveling and take care of my family. $O$ Allah, truly

\footnotetext{
${ }^{10}$ Mahima Diahloka, Op.cit., 31

${ }_{11}$ 'Abdul'aziz bin Fathi as-Sayyid Nada,Op.Cit., 6
} 
I take refuge in you from fatigue in traveling, a sad sight, and a bad situation in wealth and family when returning "12

2. Pray with friends who are righteous

The Prophet forbade speaking alone, Prophet salaullahualaihiwassalam said:

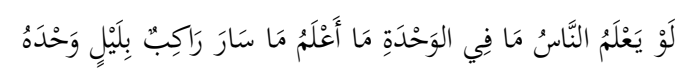

"If humans knew the danger of being alone (safar) as I know it, surely no one would travel at night"

Likewise, Rasulullahsalaullahualaihiwassalam:

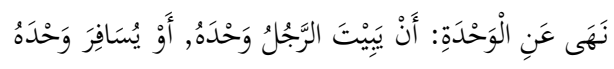

"Forbid alone, that is prohibiting staying alone or having a safar alone"13

3. Friends of no less than three people

Friends in safar are at least three people. And that is the perfection of adab taught by the Prophet salaullahualaihiwassalam.

Rasulullah salaullahu 'alaihiwassalam said:

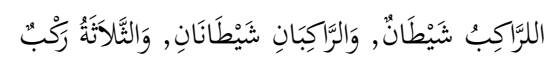

"One traveler is Satan, two travelers are shaitan, and three travelers are ideal groups (far from shaitan) ${ }^{\prime 14}$

4. Choosing one to become a leader when speaking, where the leader is tasked to be responsible for the ongoing safar. ${ }^{15}$

Rasulullah salaullahu 'alaihiwassalam said:

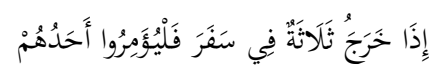

\footnotetext{
${ }^{12} \mathrm{Ibid}, 15$

${ }^{13} \mathrm{Ibid}, 8$

${ }^{14} \mathrm{Ibid}, 9$

${ }^{15}$ Mahima Diahloka, Buku Pintar "Beribadah..., 31
} 
Jurnal Hunafa: Studia Islamika, Volume 16, Number 1, p. 88-110

E-ISSN: 2355-7710

P-ISSN: 1411-125X

"If three people come out on a journey, let them show one of them to be a leader"116

Preferably the chosen leader is the most important person who is best in religion, the most polite, the most courageous, the most gentle, the wisest, and the most experienced. Because, such people will be closer to the truth. ${ }^{17}$

A traveler always obeys their leader as long as the leader does not command disobedience.

Rasulullah salaullahualaihiwassalam said:

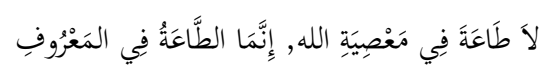

"There is no obedience in doing evil to Allah. Indeed, obedience is only to things that are ma'ruf ${ }^{\prime \prime 18}$

5. Increase prayer and dzikr during the journey, because prayer protects the traveler, namely the perfect prayer.

6. If he is in the lowlands he glorifies, and when he is in the highlands he recites takbir.

7. Serve and take ibrah from everything he sees during Safar.

8. Hurry to meet his needs, so he hurries to return to his family. ${ }^{19}$

Prophet salaullahualaihiwassalam said:

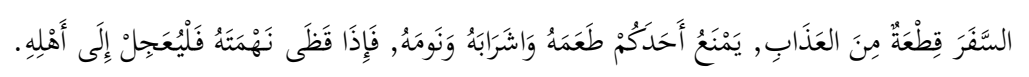

16 'Abdul'aziz bin Fathi as-Sayyid Nada,Ensiklopedi Adab Islam..., 11

${ }^{17}$ Ibid

${ }^{18} \mathrm{Ibid}$

${ }^{19}$ Mahima Diahloka, Buku Pintar "Beribadah..., 31 
"Safar is part of the punishment because someone is prevented from eating, drinking, and sleeping, so if one has adjusted his interests, let him go home immediately to his family"20

Ethics when returning home in a row

1. Buy gifts for family as limited as your abilities.

2. Pray in the vehicle.

3. Tell the family before arriving so that you don't surprise them, and they get ready to welcome you. ${ }^{21}$

Prophet salaullahu 'alaihi wassalam said to his companions upon returning from safar:

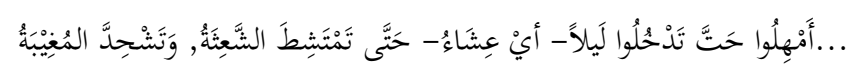

22"... Hold it first until you don't enter night time, namely Isha 'time, so that women who mess their hair can preen and dress their hair and women who have long been left behind can shave their pubic hair"

4. At the time of arrival, make the mosque the starting place before he is home. And perform the two rak'ah prayers in the mosque, as the Prophet salaullahu 'alaihi wassalam did.

5. Welcome the arrival of people who come to meet and shake hands with him. ${ }^{23}$

\section{Mahram for Women}

A woman is highly respected in Islam, in which Islam maintains even a lot of rules that are specific to a woman. In the Qur'an there is also a surah that explains a woman, in the sense that a woman is truly upheld, even highly glorified in Islam. One

20 'Abdul'aziz bin Fathi as-Sayyid Nada, Op.Cit., 23

${ }^{21}$ Mahima Diahloka, Buku Pintar "Beribadah..., 31

22 'Abdul'aziz bin Fathi as-Sayyid Nada, Ensiklopedi Adab Islam, 24

${ }^{23}$ Mahima Diahloka, Buku Pintar "Beribadah..., 31 
of them in Islam regulates adab if a woman wants to do safar or a journey that must be accompanied by her mahram, this is to maintain the safety and honor of a woman.

Before discussing further about the law of women who conduct safar, we must know what mahram is, who is included in our mahram and what are the conditions for a mahram that can accompany a woman to be grateful.

According to the language of the word mahram(المجرم) comes from Arabic co

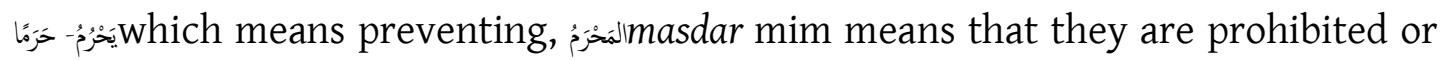
forbidden. ${ }^{24}$

Mahram is all people who are forbidden to marry forever because of heredity, milk kinship and marriage in Islamic law. Mahram for a woman is a person who is forbidden to marry a woman, both forever and temporarily. ${ }^{25}$ Sheikh Shaleh Al Fauzan Hafidzhahullah said; "Mahram for a woman is her husband and all those who are forbidden to marry forever because of patronage, such as father, son and brother, or from other causes such as brother, father or stepson." ${ }^{26}$

There are also several types of mahram:

1. Mahram Because of Nasab

There is a verse in the Qur'an that explains mahram for women in Sura An-Nisa verse 23

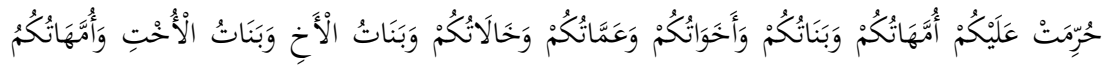

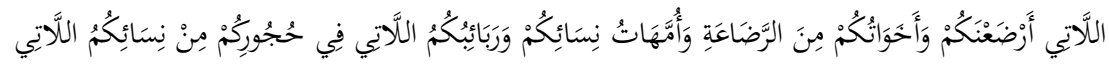

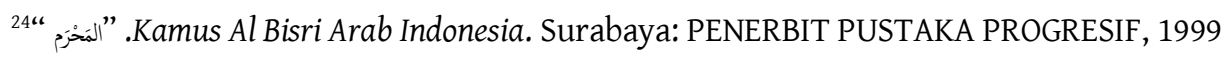

${ }^{25}$ Mufida, Skripsi: "HUKUM PERJALANAN HAJI WANITA TANPA MAHRAM (Perbandingan Mazhab Hanafi dan Mazhab Syafi'T" (Banda Aceh: UNIVERSITAS ISLAM NEGERI AR-RANIRY, 2016), 32.

${ }^{26}$ Mas badar, "Mahram Bagi Wanita", https://masbadar.com, diakses pada selasa, 21 Mei ,2019 pukul 19.49, 1 


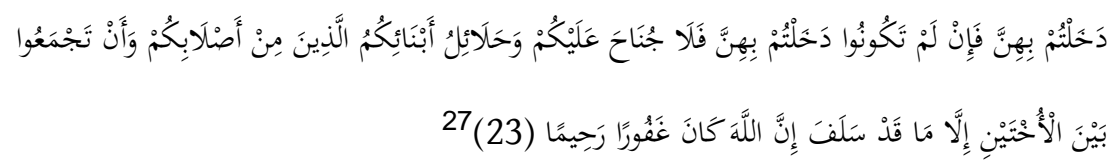

"Forbidden to you are your mothers, your daughters, your sisters, your father's sisters and your mother's sisters, your brother's daughters and your sister's daughters, your milk-mothers, your milk-sisters, the mother of your wives, and the stepdaughters who are your foster-children, born of your wives with whom you have consummated blame upon you (if you marry their daughters). It is also forbidden for you to take the wives of the sons who have sprung from your lions and to take two sisters together in marriage, although what is past is past. Surely Allah is all forgiving, all compassionate.. QS. AnNisa': 23

Some mahram for a woman because of kinship, who can accompany her when she wants to do safar:

a. Father, grandfather and so on, both father and mother.

b. Her son, her son's son, her daughter's son and so on down.

c. Biological Brother, brother from the same father and brother from the same mother.

d. Nephew from her brother, the son of her brother from the same father and the son of her brother from the same mother.

e. Nephew from her sister and the son of the sister who is from the same mother.

f. His uncle (his father's brother)

g. Mother's brother, either brother from the samefather, or brother from the samemother ${ }^{28}$

2. Mahram from the same milk (Radha'ah)

\footnotetext{
${ }^{27} \mathrm{Al}$ Quran

${ }^{28}$ Holilur Rohman, Reinterpretasi Konsep Mahram Dalam Perjalanan Perempuan Pespektif Hermeneutika Fazlur Rahman 508
} 
Radha'ah is the process of breastfeeding. Radha'ah can make people become mahram. Radha'ah itself is sucking milk from the breast. According to the term Radha'ah figh means breastfeeding a child. According to the dictionary, figh of children who suckle are called mutadhi, while nursing women / mothers are called murtadhi'ah, and owners of milk (men who impregnate women who breastfeed) are called fadl or Shahibul Laban. ${ }^{29}$

Mahram which is caused by milk is:

a. Milk Father

That is the husband of the milk mother. Included as mahram and the milk grandfather, who is the father's father or mother from the same milk.

b. Son from the milk mother

Including milk children who are the grandson of milk children both male and female.

c. Brother from the same milk

Either he is a biological milk brother, or stepbrother.

d. Feeding Nephew

The child of the sibling from the same milk.

e. Milk Uncle

Namely the brother of milk father or mother. ${ }^{30}$

There are a number of explanations regarding the amount of milk sucked by the baby, which makes it can be said to be a milk sibling or not included as mahram.

${ }^{29}$ Wikishia, Radha'ah (http://.mobile.wikishia.net/index.php/Radha'ah_(Menyusui))diakses pada tanggal 20 Juni 2019, 2016

30 "Mahram Bagi Wanita", Op.Cit., 1 
1157."From Ayesha, She said: Has said the Prophet sallallaahualaihiwassallam: " occasionally once or twice suction can not be forbiden" (HR. Muslim)

Explained in the book, if a child suck milk from another woman, once or twice, then it is not a child of milk for that woman. ${ }^{32}$

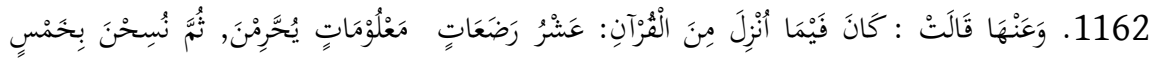

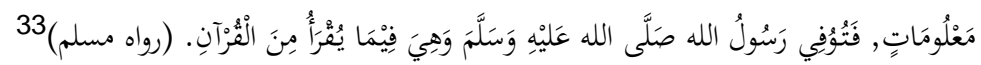

1162. "And from him. He said: "the ten implements which ma'lum forbid" are from among the verses of the Quran which were revealed, then meant by five (suckling) which is true; then Rasulullahsalalullahualaihiwassalam died in the state of the verse was read as the Quran "(HR Muslim)

\section{Information}

a. That is to say, in the Quran it has been mentioned that ten times breastfeeding makes illegitimate marriage between suckling and breastfeeding. Then five were included, then stayed five times, that is the five times make it became illegitimate marriage between suckling and breastfeeding. And the five-time suckling is still read as the Quran when Rasulullah salaullahualaihi died.

b. Based on the riwayah from Aisha about ten and five times breastfeeding cannot be considered shah with the ma'na, because if the shah is certainly in the Quran, ten feedings or, five feedings.

\footnotetext{
${ }^{31} \mathrm{IbnuHajr}$ Al 'Asqalani, Tarjamah Bulughul Maram IbnuHajr Al 'Asqalani berikut keterangan dan penjelasannya, Terj. A. Hassan (Bangil : Pustaka Tamaam, 1991), 593

${ }^{32} \mathrm{ibid}$

${ }^{33}$ Ibid, 596
} 
Jurnal Hunafa: Studia Islamika, Volume 16, Number 1, p. 88-110

E-ISSN: 2355-7710

P-ISSN: $1411-125 \mathrm{X}$

c. Five times Breastfeeding is only in the hadith, not in the Quran. ${ }^{34}$

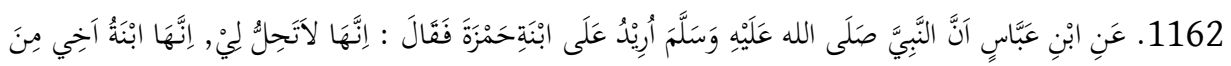

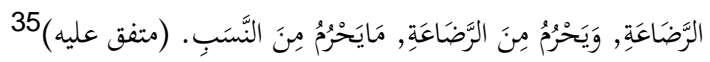

1162. "From Ibn" Abbas, the Prophet Salaullaahualaihiwassalam, was asked to marry Hamzah's child. So he said, "She is not lawful to me, because she is a child to my sister; because haram from breastfeeding is nothing that is unclean with the chapter nasab"

What is forbidden with the chapter nasab means that we are unclean or may not marry Nasab (descendants), which has been explained in the Qur' an surah An Nisa 'verse 23. If someone has suckled for another woman then it is forbidden to marry Nasab from the mother.

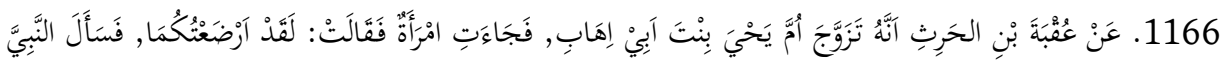

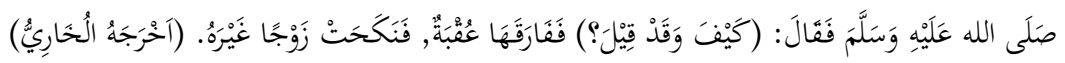

1166. "From 'Uqbah bin Harith, that he married UmmahYahyabintAbilhab then a woman came and said 'I have breastfeed you both. He asked the Prophet salaullahualaihiwassalam. Then say: "How (again) when it was said? Then 'Uqbah separated from him and married another man" issued by Bukhari ${ }^{36}$

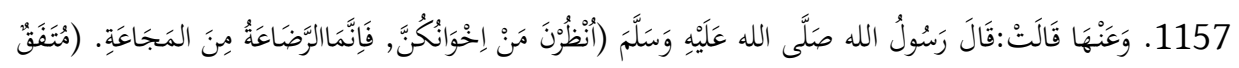

عَكَيْدِ

${ }^{34} \mathrm{Ibid}, 597$

${ }^{35}$ Ibid. 593

${ }^{36} \mathrm{Ibid}, 599$ 
1157. "And from him. He said: Have stated by the Prophet salaullahualaihiwssalam: "Pay attention, who are your brothers (milk), because there is no breastfeeding but from hunger." Mutttafaqun' Alaihi ${ }^{37}$

Explained in the text of his book that breastfeeding that makes a mother milk is as explained by "Aisha in interpreting the hadiths: "a child who is hungry there is no food that is filling but the mother's milk." 38

3. Mahram Because of Mushaharah

Mahrammushaharah is a mahram that occurs because of marriage. Said Syeikh Abdul Karim ZaidanRahimahullah; "Female Mahram caused by mushaharah are people who are forbidden to marry this woman forever like stepmother, daughter-in-law, and in-laws"139

Mahram for a woman because of marriage is:

a. The sons and daughters of their husbands, sons and daughters of their husbands' daughters and so on, whether they are from the previous wife (who has been divorced) or are still in marriage with or from wife afterward

b. The father of his husband (his father-in-law), his grandfather and so on, is the same whether the grandfather is on the side of the husband or mother's husband.

c. Daughter's husband (son-in-law) and her granddaughter's husband, both the grandson of his son or of his daughter, and so on down.

The three people mentioned are still mahram, just by carrying out the marriage contract, so that even if her husband has left her because of death or because of divorce or because of fasakh (separated marriage), then they (the three groups above) remain as mahram for her (for the woman) .

${ }^{37}$ Ibid, 593

${ }^{38} \mathrm{Ibid}$

${ }^{39}$ Mas badar, "Mahram Bagi Wanita", 1 
d. Mother's husband and grandmother's husband and so on, however, the husband could not be a mahram for his wife's daughters, until he had gathered his wife. If he has gathered them then he becomes a mahram for his wife and daughter and granddaughter's daughter, both the daughter of her previous husband or husband afterward, even though later he divorces his wife. If he just runs a marriage contract with a woman, then he divorces her before collecting it, and then she cannot be a mahram for her ex-wife's granddaughter. ${ }^{40}$

\section{Hadiths that Forbid Women to Pray without a Mahram}

1. From Ibn Abbas Radhiyallahu'anhu, he said: The Prophet sallallaahualaihiwasallam said:

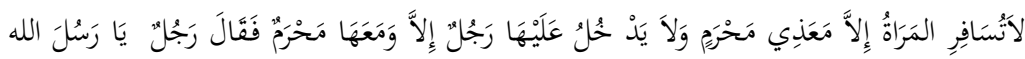

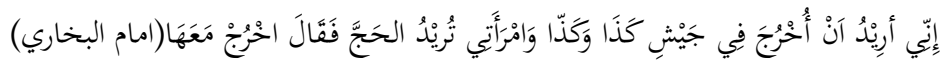

"Don't be a Safar woman (traveling far away) except together with her mahrom, and don't let a man meet her unless the woman is accompanied by her mahram. So someone said: $O$ Rosulullahshalaullahualaihiwasallam actually I want to take part in war and so on, while my wife wants to perform the Hajj. He said: Come out (go on the pilgrimage) with her (your wife) "(Narrated by Imam Bukhari) ${ }^{41}$

2. From Ibn UmarRadiyaullahu 'anhuma from the Prophet sallallaahualaihiwasallam said:

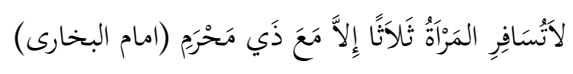

\footnotetext{
${ }^{40}$ Holilur Rohman, REINTERPRETASI KONSEP MAHRAM ..., 510

${ }^{41}$ Ummu 'Abdillah As-Salafiyah, "Hukum Safar Bagi WanitaTanpa Mahram" (https://almanhaj.or.id/2848-hukum-safar-bagi-wanita-tanpa-mahram-.html, Diakses pada 19 Juni $2019,2010)$
} 
"Let no safar woman for three days (journey) but together with her mahram" (Narrated by Imam Bukhori) ${ }^{42}$

3. From Abu Hurairah Radhiyaullahu 'anhu said: Prophet Salaullohu alaihi wa sallam said:

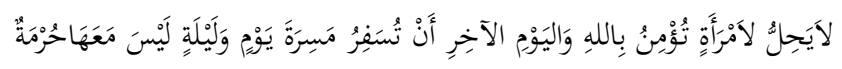

"It is not permissible for a woman who has faith in Allah and the final day of safar as long as a day (trip) with no mahram (which accompanies it)"143

4. From Qaz'ah the maid of Ziyaad said: "I heard Abu Sa'id (Al Khudry i), who had followed twelve wars with the Prophet Shalaullahualaihiwasallam which made me amazed, namely:" Let no safar woman as far as two days (trip) without a husband or mahram, do not fast on two days of Eid al-Fitr and Eid al-Adha, do not pray after doing two prayer, namely after the Asr prayer until the sun sets and after the morning prayer until the sun rises, and do not travel far except for the three mosques: Haram mosque, my mosque (Nabawi mosque) and the Aqsa mosque" ${ }^{44}$

A woman may travel alone on a day or more trip, if during the trip for the purposes of the syara allowance and is safe. Because remembering the hadith:

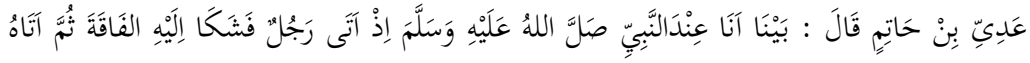

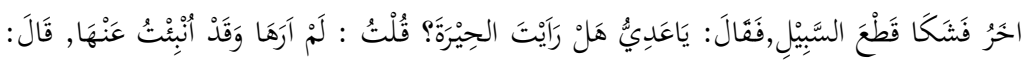

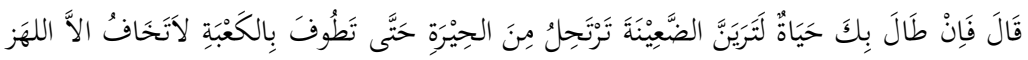

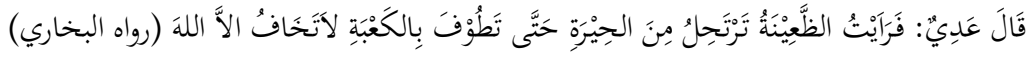

${ }^{43}$ Ibid

${ }^{44}$ Ibid 
"'Adi bin Hatim said: When I was in front of the Prophet salaullahualaihiwasallam, suddenly there was a man who came to complain to him about poverty, then came another who complained about the disturbance of the road (no security); then his word salaullohualaihiwasallam; 'Have you seen the village of Hirah, hi' Adi? 'I replied 'Not yet, but have heard the news.' He continue 'If you live long, surely you will experience the age of a woman traveling from the village of Hirah to thawaf (circumnavigating) the Ka'bah with nothing to fear but Allah subhanahuwata'ala'. Said 'Adi' in the future I saw a woman traveling from Hirah so she prayed at the Ka'bah, there was nothing to fear but Allah subhanahuwata'ala." (Narrated by Bukhari) ${ }^{45}$

5. In the Muslim history of the hadith of Abu Said al-Khudri, Rasulullah SAW said: "It is not lawful for a woman who believes in Allah and the last day to take a trip which takes more than three days, but she must be accompanied by her father, child, her husband, brother, or mahram." (Saheeh Muslim) ${ }^{46}$

6. Hadith 'Abdullah Ibn' Abbas, he said: "I heard the Messenger of Allāh sermoned, he said: "Never a man alone with a woman except the woman accompanied by her mahram, and may not be a woman traveling except with mahram, then a man arose and said: 'Surely my wife has come out to perform the pilgrimage, while I have been obliged to follow a war', then he said: 'Go and do the hajj with your wife."

7. Imam Nawawi absolutely prohibited without consideration of three days as in the hadith text above, if without a mahram. Women are the only legal subjects, who are subject to a travel ban without mahram, only because they are female. The reason that women are the cause of slander was also written by Wahbah Zuhaili when discussing the laws of women who came out to pray Eid. According to Hanafiyah and Malikiyah, they agreed that there was no rukhsah

\footnotetext{
${ }^{45}$ HIMPUNAN PUTUSAN TARJIH Pimpinan Pusat Muhammadiyah Majelis Tarjih(Yogyakarta: Suara Muhammadiyah, 2009), 288

${ }^{46}$ Holilur Rohman, “REINTERPRETASI KONSEP MAHRAM... 506

${ }^{47}$ Ibid, 507
} 
to allow women to leave in order to perform Friday prayers, two holidays, and other prayers. ${ }^{48}$ The basis of their opinion is in verse 33 of Surah al-Ahzab17, namely:

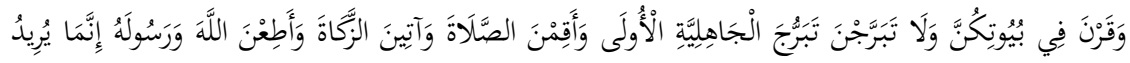

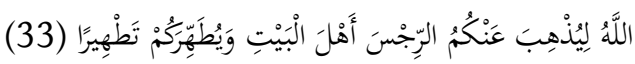

"Meaning: And let you remain in your house and do not decorate and behave like the Jahiliyahs previously and establish prayer, give alms and obey Allah and His Messenger. Verily, Allah intends to eliminate sin from you, O Ahlul bait and cleanse you as clean as possible." ${ }^{49}$

\section{Courtesies to Go Out for a Woman}

A woman who wants to leave home needs to complete or fulfill various conditions, to avoid many things that are not desirable and unexpected. In Islam, a woman who wants to go out of her house or have a funeral is arranged in a way that is in accordance with the Islamic Shari'a, which must be done and must be abandoned. Where Islam is very protective, respecting a woman.

As for a number of people, if a woman wants to leave the house as follows:

1. A woman may leave the house if she has a need that is very necessary which is required by the Shari'a. As:

a. Demanding science fardain

b. Pilgrimage to relatives, neighbors or friends.

c. Getting out of making a halal living is because she is alone or in poor condition or her guard is sick or disabled.

d. To be a witness. Rasulullah salaullahualaihiwasallam said: "Indeed Allah has permitted you (ie women) out of your house (the truth, which is not immoral)".

${ }^{48}$ Holilur Rohman, “REINTERPRETASI KONSEP MAHRAM... 511

${ }^{49} \mathrm{Al}$ Quran 
2. Out of the house by praying for protection from slander and disturbances of humans and Satan.

3. If the destination is less than two marhalah (48 stones) women can be accompanied by her children. If traveling further than that, should be accompanied by the mahram.

4. Have to cover her body so that:

a. It is easy to recognize that he is a woman of faith.

b. There is no interference.

c. Get the forgiveness of Allah subhanahuwata'ala.

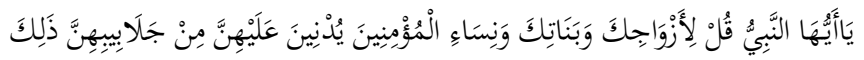

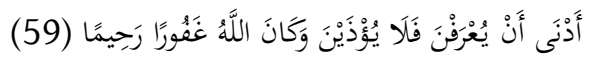

"O Prophet, say to your wives and your children and also women who believe that they will drop (anchor) the veil throughout their bodies. That is the best way for them to be recognized, so they will not be disturbed. And Allah is Forgiving and Most Merciful" (QS. Al Ahzab: 59) ${ }^{50}$

5. Avoid walking in a big street full of crowded people. Should walk on the side that is not a public street.

6. Do not expose your jewelry (such as necklace, bracelets, etc.) or set foot to ring jewelry (such as anklets or boots).

7. Walk politely. Avoid lots of talks in the street.

8. Don't use perfume because it arouses male lust. If you wear it, not too much, it's enough to just not stink.

9. Submitting your eyes and put an end to shame. Never greet or serve men who are not mahram.

${ }^{50} \mathrm{Al}$ Quran 
10. Request forgiveness from Allah subhanahuwata'ala throughout the journey ${ }^{51}$

\section{Conclusion}

1. From the foregoing we know that in a way of doing Safar or traveling in Islam it has been arranged for a traveler to leave home or while traveling such as:

a. When leaving the house pray with do'a out of the house

b. Travel with friends who are righteous

c. When travelling there are no less than three people

d. Choose one to be a leader when speaking

e. Increase prayer and dzikr during the journey

f. When he is in the lowlands he glorifies, and when he is in the highlands he is anchored.

g. Serve and take ibrah from everything he sees during Safar

h. Hasten to return to his family.

i. Bring souvenirs to those at home

j. Notify family before arriving

k. Make the mosque the main destination when you arrive

2. Mahram is a mahram because of nasab as described in QS. An Nisa verse 23

3. There are several traditions that explain the prohibition against a woman in traveling without a mahram like the hadith of Ibn Abbas Radhiyallahu'anhu, he said: Prophet Shalaullahualaihiwasallam said:

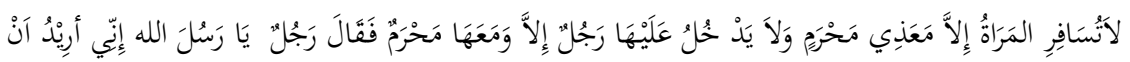

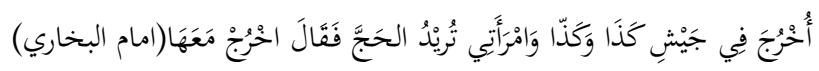

"Woman shouldn't go for a safar (traveling far away) except together with her mahrom, and don't let a man meet him but the woman is accompanied by her mahram. So someone said: O Rosulullahshalaullahualaihiwasallam actually I want to

${ }^{51}$ Giliran Timur, Panduan Wanita Sholehah: ke Arah Membentuk Keluarga Bahagia. Vol. 2 dari Panduan Hidup (GiliranTimur Books: 2008) , 77 
Jurnal Hunafa: Studia Islamika, Volume 16, Number 1, p. 88-110

E-ISSN: 2355-7710

P-ISSN: $1411-125 \mathrm{X}$

take part in war and so on, while my wife wants to perform the Hajj. He said: get out (go on the pilgrimage) with her (your wife) "(Narrated by Imam Bukhari)

And the hadith narrated by Muslims from Abu Said al-Khudri, Rasulullah SAW said: "It is not lawful for a woman who has faith in Allah and the last day to take a trip which takes more than three days, but she must be accompanied by her father, child, her husband, brother, or mahram." (Saheeh Muslim)

4. If a woman wants to leave home only if she really has a very urgent need,
a. Not patient and must cover the body
b. Have to be polite
c. If the trip is far, she must be accompanied by a mahram
d. Does not reveal self-sufficiency
e. Do not snap your foot so that the jewelry is known
f. Not talk about things that invite the passions of a man
g. Asking forgiveness to Allah subhanahuwata'ala

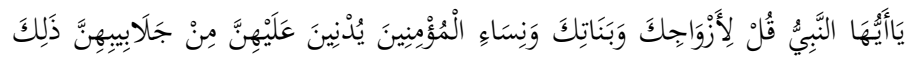

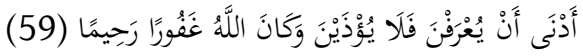

"O Prophet, say to your wives and your children and also women who believe that they will drop the veil all over their bodies. That is the best way for them to be recognized, so they will not be disturbed. And Allah is Forgiving and Most Merciful"(QS. Al Ahzab: 59)

\section{Reference}

'Abdul'aziz Bin Fathi As-Sayyid Nada, Ensiklopedi Adab Islammenurut Al Quran Dan As Sunnah, Terj. Abu Ihsan Al Atsari (Jakarta: Timpustaka Imam Asy-Syafi'i, 2007)

Ahmat Sarwat, Seri Figh Kehidupan (3): Shalat (Jakarta: Rumah Fiqih Publising, 2015)

Ali Mansur, Hukum Dan Etika Pernikahan Dalam Islam (Malang: Universitas Brawijaya Press, 2017) 
Jurnal Hunafa: Studia Islamika, Volume 16, Number 1, p. 88-110

E-ISSN: 2355-7710

P-ISSN: $1411-125 \mathrm{X}$

Enang Hidayat, Fiqih Ibadah Bagi Orang Sakit Dan Bepergian (Bandung: Cendekia Press, 2015) Fadhl Ihsan, "Safar Dan Macam-Macamnya" (Https://Www.Google.Com/Amp/S/Fadhlihsan.Wordpress.Com/2010/06/24safarDan-Macam-Macamnya/Amp/), Diakses Pada 28 Mei 2019, Pukul 20.03

Giliran Timur, Panduan Wanita Sholehah: Ke Arah Membentuk Keluarga Bahagia. Vol. 2 Dari Panduan Hidup (Giliran Timur Books: 2008)

Himpunan Putusan Tarjih Pimpinan Pusat Muhammadiyah Majelis Tarjih (Yogyakarta: Suara Muhammadiyah, 2009), Hal. 288

Holilur Rohman, Reinterpretasi Konsep Mahram Dalam Perjalanan Perempuan Pespektif Hermeneutika Fazlur Rahman

Ibnu Hajr Al 'Asqalani, Tarjamah Bulughul Maram Ibnu Hajr Al 'Asqalani Berikut Keterangan Dan Penjelasannya, Terj. A. Hassan (Bangil : Pustaka Tamaam, 1991)

Mahima Diahloka, Buku Pintar “Beribadah Dalam Perjalanan” (Jakarta: Lembar Langit Indonesia, 2016)

Mas Badar, "Mahram Bagi Wanita”, Https://Masbadar.Com, Diakses Pada Selasa, 21 Mei ,2019 Pukul 19.49

Mufida, Skripsi: "Hukum Perjalanan Haji Wanita Tanpa Mahram (Perbandingan Mazhab Hanafi Dan Mazhab Syafi'i” (Banda Aceh: Universitas Islam Negeri Ar-Raniry, 2016)

Said Bin Ali Wahf Al Qahthani, Ensiklopedi Shalat Menurut Al Quran Dan As Sunnah, Terj. M. Abdul Ghafar (Jakarta: Tim Pustaka Imam Syafi'i, 2006)

Ummu "Abdillah As-Salafiyah, "Hukum Safar Bagi Wanita Tanpa Mahram" (https://almanhaj.or.id/2848-hukum-safar-bagi-wanita-tanpa-mahram-html, Diakses pada 19 Juni 2019, 2010) 